\title{
PEMANFAATAN SMARTPHONE SEBAGAI MEDIA PEMBELAJARAN MATA KULIAH KOREOGRAFI DAN KOMPOSISI TARI I
}

\author{
Gita Kinanthi Purnama Asri (Adinda) ${ }^{1}$
}

\section{Pendidikan Seni Tari STKIP PGRI Banjarmasin}

gitakinanthipa@gmail.com

\begin{abstract}
ABSTRAK
Penelitian ini membahas tentang pemanfaatan smartphone sebagai media pembelajaran mata kuliah koreografi dan komposisi tari I. Substansi mata kuliah ini adalah memberikan pengalaman dan pengetahuan tentang seni menata, menyusun, mengungkapkan gagasan yang berdasarkan unsur-unsur tari sehingga menjadi suatu kesatuan yang sarat dengan nilai estetik dan ikut serta membangun karakter masyarakat serta melestarikan kebudayaan lokal. Alma M Hawkins menyatakan terdapat tiga tahap proses koreografi yaitu tahap eksplorasi, improvisasi, dan pembentukan. Tentu saja pembelajaran ini tidak boleh ketinggalan zaman, sehingga perlu suatu yang inovatif dalam aktivitasnya. Kehadiran smartphone yang menjadi pusaka serta budaya baru di kalangan milenial menjadi inspirasi dari penelitian ini. Tujuannya adalah (1) mendeskripsikan penggunaan smartphone yang terintegrasi dengan internet sebagai media pembelajaran untuk penelusuran, pemberianpenerimaan informasi (2) mendeskripsikan penggunaan smartphone sebagai media komunikasi pembelajaran (3) mendeskripsikan manfaat smartphone sebagai sistem pendokumentasian selama proses pembelajaran koreografi dan komposisi tari I. Metode yang digunakan dalam penelitian ini adalah metode kualitatif dengan pendekatan deskriptif, menggunakan sampling purposive yaitu mahasiswa angkatan 2017 Program Studi Pendidikan Seni Tari STKIP PGRI Banjarmasin berjumlah 30 orang. Teknik pengumpulan data dengan cara observasi, wawancara dan dokumentasi.Teknik analisis data menggunakan deskriptif interpretatif. Hasil penelitian ini adalah terciptanya suasana pembelajaran yang lebih efektif dalam proses transfer informasi, komunikasi yang terjalin antara dosen mahasiswa terjadi lebih ringan dan menyenangkan, interaktif dalam mengekspresikan hasil belajar, menghasilkan dokumen proses pembelajaran sehingga memberi kemungkinan untuk dosen dan mahasiswa saling mengembangkan pikiran, memotivasi diri dan keterampilannya dalam pembelajaran koreografi dan komposisi tari. Secara spesifik smartphone mampu menjadi (1)alat penelusuran informasi dan pengetahuan (berbagi, memberi dan menerima)koreografi melalui penggunaan google dan youtube (2)alat komunikasi atau perantara antara mahasiswa dan dosen secara tidak tatap muka dan diutamakan di luar jadwal kuliah, dimanfaatkan untuk konsultasi dan pendistribusian tugas kuliah, peran aplikasi whatsapp, email dan instagram sangat menguntungkan dalam memonitor tugas koreografi(3)alat perekam dan pencatatan pada proses pembelajaran koreografi, sehingga menghasilkan dokumen yang tersimpan dan mampu menjadi pendukung dalam sistem evaluasi pembelajaran koreografi di kemudian hari.
\end{abstract}


Gita Kinanthi Purnama Asri / LENTERA Jurnal Ilmiah Kependidikan

Vol. 14 No.2 (Juli - Desember 2019 Edisi Dies Natalis XXXIV) 65-74

Kata Kunci: Smartphone, Media Pembelajaran, Koreografi dan Komposisi Tari I

\section{PENDAHULUAN}

Bayu Endro Winarko selaku Ketua Bidang Kajian Kebijakan Publik Generasi Optimis (GO) Indonesia menyatakan bahwa "Digital tidak sekedar teknologi seperti AI (Artificial Intelligence), big data, IoT (Internet of Things), atau digital voice, tapi menyangkut habit atau budaya. Pesatnya teknologi apabila tidak diarahkan dan digunakan dengan tepat, akan menjadi sia-sia". Pernyataan tersebut menjadi perhatian bagi kita agar tidak sekedar mengikuti arus perkembangan zaman yang serba high tech sebagai trend baru namun diharapkan mampu memanfaatkannya dan menjadikannya budaya dengan penyikapan yang bijak sehingga membawa kebaikan dalam kehidupan.

Era digital memang telah merasuki dan akrab di berbagai kalangan masyarakat zaman now. Banyak terobosan yang tiba-tiba muncul dan menjadi tradisi baru. Hal ini juga berdampak pada dunia pendidikan yang ditandai dengan perubahan atau pengembangan pola mengajar tradisional menuju pola mengajar modern dengan memanfaatkan berbagai macam teknologi informasi dan komunikasi (TIK). Pembelajaran di era digital ini tidak cukup hanya suatu ketrampilan untuk dirinya sendiri melainkan tercakup didalamnya suatu ketrampilan untuk hidup bermasyarakat, berbangsa dengan suatu semangat kesamaan dan kesejajaran (learning to live together) (Anwar, 2004:5).

Kemajuan TIK, menimbulkan efek terhadap pengembangan cara pikir, keterampilan, dan hubungan komunikasi antara peserta didik dan pendidik. Keduanya berusaha untuk beradaptasi dengan gaya hidup serba online yang diterapkan dan dimanfaatkan dalam mengoptimalkan pembelajaran sehingga mencapai tujuan pembelajaran yang berorientasi pada revolusi industri 4.0. Melalui pemanfaatan TIK yang terintegrasi dengan internet diharapkan dapat mempermudah dalam mencari dan berbagi informasi, pengelolaan, penyimpanan dan transfer ilmu pengetahuan.

Salah satu wujud kecanggihan informasi dan komunikasi yang disebut dengan smartphone android mampu mencuri hati masyarakat masa kini dan layak untuk dieksplorasi. Smartphone bukan sekedar alat komunikasi seperti handphone biasa yang berfungsi sebatas telepon dan pesan singkat. Smartphone merupakan perangkat seluler yang dilengkapi dengan sistem operasi layaknya komputer, dapat mengimplementasikan berbagai bentuk multimedia. Spesifikasi keunggulan smartphone ialah memiliki mobilitas yang tinggi dan dapat dioperasikan secara lebih efektif. Keberadaan smartphone dan aksesnya ke internet di kalangan mahasiswa telah menarik perhatian dan menjadi suatu kebutuhan atas eksistensi dirinya sehingga menjadi lifestyle.

Berdasarkan kondisi tersebut, sudah seharusnya dosen memfasilitasi mahasiswa untuk menggunakan smartphone sebagai media pendukung pembelajaran. Media pembelajaran adalah alat bantu dalam proses belajar dan mengajar, segala sesuatu yang dapat dipergunakan untuk merangsang pikiran, perasaan, perhatian dan kemampuan atau keterampilan pembelajar melalui kegiatan komunikasi dan sehingga dapat mendorong terjadinya proses belajar dapat dikatakan sebagai media pembelajaran. Pada perkembangannya dalam kegiatan pedidikan media digunakan 
sebagai sumber belajar yang dapat memberikan pemahaman yang mengacu pada kenyataan bagi peserta didik, jenis media yang banyak digunakan dalam kegiatan pembelajaran adalah media dengan jenis multimedia. (Ruth Lautfer, 1999) bahwa media pembelajaran adalah salah satu alat bantu mengajar bagi guru untuk menyampaikan materi pengajaran, meningkatkan kreatifitas siswa dan meningkatkan perhatian siswa dalam proses pembelajaran. Dengan media siswa akan lebih termotivasi untuk belajar, mendorong siswa menulis, berbicara dan berimajinasi semakin terangsang. Dengan demikian, melaluimedia pembelajarandapat membuat proses belajar mengajar lebih efektif dan efesien serta terjalin hubungan baik antara guru dengan peserta didik. Selain itu, media dapat berperan untuk mengatasi kebosanan dalam belajar di kelas.

Smartphone sebagai media pembelajaran diposisikan sebagai perantara atau penghubung antara dosen dan mahasiswa. Media pembelajaran harus mampu menarik dan menuntun mahasiswa dalam memahami materi pembelajaran agar lebih efektif, efisien dan dinamis. Laurillard (2007) berpendapat bahwa dengan menggunakan smartphone dalam pendidikan, membuat teknologi ini memiliki peran yang sentral untuk dapat digunakan sebagai sarana penyampai informasi kepada siswa melalui teknologi perangkat mobile. Pemanfaatan smartphone sebagai media pembelajaran didukung oleh Rogozin (2012:913) yang menyatakan bahwa dengan menggunakan smartphone sebagai media pembelajaran memberikan kesempatan belajar yang lebih mendalam bagi siswa karena dengan menggunakan smartphone siswa dapat mengembangkan pembelajaran melalui penelusuran informasi dari internet, serta melatih keterampilan mereka dalam melaksanakan praktikum karena prinsip mobilitas yang dimiliki oleh smartphone. Lebih lanjut dikatakan bahwa dengan menggunakan smartphone siswa mampu membangun kompetensi mereka dengan cara yang dinamis.

Penelitian ini membahas tentang pemanfaatan smartphone sebagai media pembelajaran mata kuliah Koreografi dan Komposisi Tari I. Menurut Alma M.Hawkins, seorang ahli tari dari Amerika menyebutkan bahwa konsep koreografi adalah berupa pemikiran-pemikiran yang diterapkan untuk mewujudkan suatu bentuk dan gaya suatu tata susunan tari (Wahyudiarto,2014:3). Mata kuliah ini menjadi bekal pengalaman kreatif mahasiswa program studi pendidikan seni tari STKIP PGRI Banjarmasin. Substansi pembelajaran ini adalah memberikan pengalaman dan pengetahuan tentang seni menata, menyusun, mengungkapkan gagasan yang berdasarkan unsur-unsur tari sehingga menjadi suatu kesatuan yang sarat dengan nilai estetik dan ikut serta membangun karakter masyarakat serta melestarikan kebudayaan local. Keterlibatan wiraga, wirama dan wirasa menjadi bagian tak terpisahkan dalam proses koreografi. Alma M Hawkins membagi proses koreografi menjadi tiga tahapan yaitu eksplorasi, improvisasi, dan komposisi. Bagi seorang yang penari maupun koreografer yang ingin mempermudah untuk mengembangkan kreativitasnya dalam proses koreografi, nampaknya tahap-tahap itu harus dipahami dan dilalui dengan sungguh-sungguh. Hubungan ke tiga tahap itu merupakan satu kesatuan dalam proses koreografi (Hadi,2011:70).

Mata kuliah ini berbobot 2 sks dengan jumlah pertemuan 16 kali setiap pertemuan berdurasi 100 menit. Tujuan pembelajaran ini antara lain: 
1. Memberikan bekal pengalaman dan kemampuan dalam meyusun serta menata tari yang berbasis tema kearifan lokal

2. Membangun nilai pendidikan karakter melalui pembelajaran koreografi dan komposisi tari

3. Memahami koreografi sebagai aset ilmu pengetahuan dalam pendidikan seni budaya

4. Menguasai konsep koreografi dan mampu menerapkannya dalam suatu karya tari

5. Mampu mengekspresikan dan mengapresiasi koreografi sebagai bentuk karya seni yang bernilai pendidikan

Mahasiswa wajib mengikuti ujian tengah semester, mengerjakan tugas, dan

ujian akhir semester. Dilihat dari perbandingan jumlah pertemuan, durasi pembelajaran, beban kuliah maka kondisi ini dirasa kurang efektif dalam mencapai tujuan pembelajarannya. Sebab, mata kuliah ini memerlukan intensitas dalam observasi, diskusi dan praktik. Sehingga, dosen dan mahasiswa memerlukan aktif dan kreatif dalam membangun kompetensinya. Maka dengan melibatkan peran smartphonesebagai media pembelajaran kekinian di kalangan mahasiswa dianggap relevan untuk mendukung dan mengoptimalkan ketuntasan pembelajaran koreografi dan komposisi tari I.

\section{METODE PENELITIAN}

Penelitian ini menggunakan metode kualitatif, menurut Bogdan dan Taylor (1992) penelitian kualitatif adalah salah satu prosedur penelitian yang menghasilkan data deskriptif berupa ucapan atau tulisan dan perilaku orang-orang yang diamati. Metode penelitian Kualitatif adalah metode penelitian yang berlandaskan pada filsafat postpositivisme, digunakan untuk meneliti pada kondisi obyek yang alamiah, (sebagai lawannya adalah eksperimen) dimana peneliti adalah sebagai instrument kunci, teknik pengumpulan data dilakukan secara triangulasi (gabungan), analisis data bersifat induktif/deduktif, dan hasil penelitian kualitatif lebih menkankan makna daripada generalisasi (Sugiyono, 2018: 9)

Penggunaan teknik sampling purposive dianggap sesuai dalam penelitian ini. Sampel penelitian ini adalah mahasiswa angkatan 2017 Program Studi Pendidikan Seni Tari STKIP PGRI Banjarmasin yang berjumlah 30 orang. Teknik pengumpulan data dengan cara observasi, wawancara dan dokumentasi. Teknik analisis data yang digunakan adalah deskriptif interpretatif, yaitu memaparkan data secara keseluruhan terlebih dahulu. Setelah data terkumpul, peneliti menginterpretasikan kemudian menganalisis.

Penelitian ini dilakukan selama tiga bulan dan tidak seutuhnya terikat di satu lokasi karena fokus penelitian ini adalah pemanfaatan smartphone yang bersifat mobile (tidak harus bertatap muka). Namun, sesekali penelitian ini juga dilaksanakan di satu tempat terpadu yaitu kampus STKIP PGRI Banjarmasin sebagai ruang belajar mata kuliah Koreografi dan Komposisi Tari I. 


\section{HASIL DAN PEMBAHASAN}

Pembahasan ini mendeskripsikan temuan-temuan manfaat yang diberikan smartphone sebagai media pembelajaran mata kuliah koreografi dan komposisi tari I. Berdasarkan observasi awal pada sampel penelitian yaitu 30 mahasiswa angkatan 2017 Program Studi Pendidikan Seni Tari STKIP PGRI Banjarmasin, diketahui semuanya memiliki smartphone. 70\% telah menggunakannya sejak tingkat SMP dan sisanya sejak SMA. Berdasarkan wawancara, aplikasi yang paling sering dan menjadi wajib bagi mahasiswa adalah facebook, messenger, twitter, whatsapp, email, instagram, google, chrome, berbagai online shop, riding online dan youtube. Rata-rata aplikasi tersebut untuk memenuhi kebutuhan keseharian mereka sebagai alat komunikasi untuk menampilkan eksistensi diri, berbagi informasi, berbisnis dan berbelanja, pemesanan transportasi online dan paling banyak adalah untuk kepentingan hiburan misalnya bermain online games. Semuanya telah menjadi habit atau kebiasaan baru yang hampir tak terlepaskan dari dunia mahasiswa zaman now. Berdasarkan hal tersebut maka selayaknya smsartphone memiliki peran di kehidupan mahasiswa sebagai media pembelajaran yang menyenangkan dan efektif.

Adapun hasil penelitian ini adalah terciptanya suasana pembelajaran yang lebih efektif dalam proses transfer informasi, komunikasi yang terjalin antara dosen mahasiswa terjadi lebih ringan dan menyenangkan, interaktif dalam mengekspresikan hasil belajar, menghasilkan dokumen proses pembelajaran sehingga memberi kemungkinan untuk dosen dan mahasiswa saling mengembangkan pikiran, memotivasi diri dan keterampilannya dalam pembelajaran koreografi dan komposisi tari. Namun, penggunaan smartphone sebagai media pembelajaran masih memerlukan arahan yang bijak yang mengandalkan peran dosen sebagai pendidik. Sebab, kelemahan mengunakan smartphone adalah mampu menjadikan penggunanya kecanduan dan melupakan realita. Hal ini dapat diantisipasi dalam perwujudan pembuatan tata tertib penggunaan smartphone dalam pembelajaran sehingga mudah dalam mengendalikan dan mengurangi resiko penyalahgunaan.

Secara spesifik smartphone mampu menjadi (1)alat penelusuran informasi dan pengetahuan (berbagi, memberi dan menerima)koreografi melalui penggunaan google dan youtube (2) alat komunikasi atau perantara antara mahasiswa dan dosen secara tidak tatap muka dan diutamakan di luar jadwal kuliah, dimanfaatkan untuk konsultasi dan pendistribusian tugas kuliah, peran aplikasi whatsapp, email dan instagram sangat menguntungkan dalam monitoring tugas koreografi (3)alat perekam dan pencatatan pada proses pembelajaran koreografi, sehingga menghasilkan dokumen yang tersimpan dan mampu menjadi pendukung dalam sistem evaluasi pembelajaran koreografi di kemudian hari.

Secara spesifik smartphone telah memberikan manfaat dan dimanfaatkan dalam pembelajaran koreografi dan komposisi tari I berikut deskripsinya : 


\section{Smartphone sebagai alat penelusuran informasi dan pengetahuan (berbagi, memberi dan menerima)koreografi melalui penggunaan aplikasi google dan youtube}

Selama 16 kali pertemuan mahasiswa berhak mendapatkan materi ajar yang telah dirancang oleh dosen pengampu sesuai dengan Rencana Pembelajaran Semester (RPS). Materi ajar tersebut tidak melulu diberikan dari buku panduan koreografi. Misalnya pada pertemuan 1 dan 2 dengan materi ajar pengantar koreografi, pengetahuan dasar koreografi dan contoh karya koreografi. Dosen mengawali dengan memberi pertanyaan seperti (a) Jelaskan definisi/pengertian seni tari dan koreografi menurut anda dan menurut ahli? (b) bagaimana sejarah koreografi di Indonesia dan siapa saja koreografer Indonesia? (c) Sebutkan fungsi dan manfaat koreografi dalam dunia pendidikan? (d)Sebutkan 150 istilah/ kata yang berkaitan dengan koreografi dan komposisi tari? Setelah pemberian pertanyaan tersebut, mahasiswa diberi kesempatan untuk menjawab mandiri tanpa bantuan smartphone, dan hasilnya mereka cukup gugup dan kebingungan dalam berkomunikasi, ada pula yang malu. Hal ini sudah menjadi tradisi bagi kebanyakan mahasiswa tari, yaitu cakap dalam keterampilan namun pasif dalam komunikasi verbal. Saat kondisi inilah dosen mengarahkan mahasiswa untuk memanfaatkan aplikasi google pada smartphone masing-masing untuk mengakses informasi setelah itu bersama-sama dilakukan evaluasi dari temuan jawaban dari pertanyaan yang telah diberikan. Semua mahasiswa mendapat giliran untuk mempresentasikan temuannya. Selain itu, dosen juga mengarahkan untuk mahasiswa membuka beberapa link seperti

https://journal.uny.ac.id/index.php/imaji

https://ejournal.upi.edu/

https://ilmuseni.com/seni-pertunjukan/seni-tari/pengertian-seni-tari, http://staff.uny.ac.id/sites/default/files/pendidikan/Dra.NiNyomanSeriati,M.Hum. /DiktatKomposisidanKoreografiI2008.pdf.

Sedangkan, aplikasi youtube dikhususkan untuk transfer informasi terkait referensi koreografi yang ada di Indonesia pada umumnya dan Kalimantan Selatan pada khususnya. Pada pertemuan ke-3 mahasiswa telah diberi referensi link untuk ditelusuri seperti : https://youtu.be/_qvV0fg2_kM (tari Balingkah- STKIP PGRI Banjarmasin), https://youtu.be/MdiZmyVFSOI (Harianto Antang Uji Koreografi ISI Yogyakarta), https://youtu.be/M2rF7QpOg4k (Pinget - Ni Luh Pt Ayu Viera Agustina), https://youtu.be/eJa20PH7bl8 (Uji Koreografi 2 UNY 2017_Kembang ancak_Yudhani Prasetya Putri) https://youtu.be/_j-U429aVZg (tari berpasangan kreasi bali).

Kemudian mahasiswa diminta mencari dan menelusuri secara mandiri berbagai referensi koreografi pilihannya dan mendownloadnya. Kriterianya adalah jenis koreografi kreasi tunggal, duet, dan kelompok. Dilakukan secara berkelompok 
dan dipresentasikan di depan kelas sehingga terjadi pertukaran informasi. Kegiatan ini cukup efektif karena mahasiswa terjun langsung dan mampu memahami kriteria koreografi sesuai jenis dan seleranya. Tak jarang mereka kebingungan dalam memilih karena banyaknya referensi yang disenanginya. Pada kondisi ini dosen menjadi pengingat dan membantu memecahkan masalahnya.

\section{Smartphone menjadi alat komunikasi atau perantara antara mahasiswa dan dosen secara tidak tatap muka dan diutamakan di luar jadwal kuliah, dimanfaatkan untuk konsultasi dan pendistribusian tugas kuliah, peran aplikasi whatsapp, email dan instagram sangat menguntungkan dalam monitoring tugas koreografi.}

Kegiatan komunikasi melalui smartphone ini dimulai setelah pertemuan pertama dengan memanfaatkan aplikasi whatsapp, mahasiswa dan dosen bergabung menjadi satu group chat discussion yang bernama Kelas Koreo 1. Manfaat yang telah dirasakan antara lain, terjalin keakraban antara dosen dan mahasiswa, adanya penambahan materi ajar yang efektif di luar jam kuliah dengan suasana mengasyikan misalnya mengkomunikasikan referensi link koreografi, mengunggah konsep koreografi dan konsultasi di setiap tahapan koreografi secara berkelompok ataupun private. Komunikasi ini diupayakan sebagaimana mestinya sesuai tujuan pembelajaran, dan tetap mengedepankan etika pembelajaran antara dosen dan mahasiswa.

Pemanfaatan aplikasi instagram sebagai sarana ekspresi mahasiswa dalam menyelesaikan tugas koreografi, misalnya menemukan 150 kata tentang koreografi dan mahasiswa diwajibkan membaginya dengan cara upload insta story yang ada di aplikasi instagram. Instagram masing-masing akhirnya dihiasi dengan tugas kuliah dan menurut hasil observasi dan wawancara hal ini belum pernah dilakukan sebelumnya. Mahasiswa bebas mengekspresikan latar dan bentuk insta story mereka sehingga mampu menarik perhatian masyarakat dan informasinya menjadi bagian dari pembelajaran koreografi yang dapat dibaca masyarakat.

\section{Smartphone menjadi alat perekam dan pencatatan pada proses pembelajaran koreografi, sehingga menghasilkan dokumen yang tersimpan dan mampu menjadi pendukung dalam sistem evaluasi pembelajaran koreografi di kemudian hari.}

Kehadiran fasilitas kamera (depan dan belakang) pada smartphone, memang menawarkan berbagai keuntungan. Tugas utamanya adalah menghasilkan gambar berupa foto dan video, untuk berbagai kepentingan. Salah satunya menjadi alat bantu untuk merekam (mendokumentasikan) setiap proses yang terjadi di setiap tahapan koreografi. Pada tahapan eksplorasi, mahasiswa memiliki berbagai aktifitas seperti 
diskusi, latihan, observasi mengenai penjelajahan terkait judul, penentuan alur adegan koreografi, pencarian dan pemilihan gerak, riset objek di lapangan, memilih iringan tari, merancang desain kostum dan rias, membuat pola lantai, menentukan properti tari dan sebagainya.

Kegiatan ini tidak dapat tuntas jika mengikuti kuantitas pertemuan kelas. Sehingga, smartphone sebagai alat bantu rekam menjadi salah satu alternatif yang relevan untuk mencapai ketuntasan pembelajaran dengan cara menambah jadwal kegiatan diluar kelas. Setiap kegiatan dalam proses ini didokumentasikan yang kemudian berfungsi sebagai bukti pembelajaran dan dimanfaatkan sebagai bahan evaluasi dengan cara konsultasi yang dibimbing oleh dosennya.

Mahasiswa telah dibagi dalam beberapa kelompok, setiap kelompok berisikan 3 orang. Sejak pertemuan ke-5 masing-masing kelompok ditugaskan untuk merekam dan menyimpan hasil dokumentasi untuk dikonsultasikan setiap minggunya, pengiriman foto atau video dengan memanfaatkan aplikasi whatsapp. Video disetor sebelum jadwal kuliah, sehingga evaluasi dilakukan secara tatap muka, memudahkan mahasiswa mengerti hasil konsultasi yang diberikan. Selain sebagai bahan evaluasi, rekaman ini juga sebagai alat pengingat yang dapat diulang bagi kelompok terkait gerakan dan alur yang telah disusun.

Pemanfaatan kamera yang ada di smartphone untuk merekam dan mengambil gambar, bahkan aplikasi notes juga digunakan untuk mendokumentasikan proses pembelajaran koreografi. Manfaat yang signifikan dirasakan adalah memudahkan proses pembelajaran bagi dosen dan mahasiswa dalam mengukur setiap perkembangan yang terjadi pada setiap tahapan proses koreografi(eksplorasi, improvisasi dan pembentukan) di setiap kelompok.

Selain itu, pemanfaatan ini menghasilkan kesadaran atas pentingnya proses dan hasil dokumentasi, terjalinnya kerjasama antara anggota disetiap kelompok, dan sebagai wujud nyata sebuah pembelajaran praktikum karena terdapat produk berupa dokumen proses dan hasil pembelajaran koreografi dan komposisi tari I. Kita ketahui bahwa seni pertunjukan merupakan bagian dari seni sesaat, sehingga sistem pendokumentasian dirasa penting untuk diperhatikan sebagai media pendukung walau menggunakan smartphone sehingga memunculkan kemungkinan untuk dikaji dikemudian hari.

Hasil proses per kelompok disimpan sebagai arsip pembelajaran koreografi dan komposisi tari I angkatan 2017. Data berupa format Mp4 dan berjumlah sekitar 8 video setiap kelompok yang berisikan proses pembelajaran dan 1 hasil pemeblajaran berdurasi kurang lebih 5-6 menit. Data ini mampu menjadi media pembelajaran berkelanjutan yang mampu dikembangkan lagi. 


\section{SIMPULAN}

Berdasarkan Berdasarkan pembahasan dalam penelitian ini dapat disimpulkan bahwa tujuan umum pembelajaran mata kuliah koreografi dan komposisi tari I adalah memberikan bekal pengalaman kepada mahasiswa untuk mampu membuat suatu karya tari dengan berbagai konsep koreografi dan berbasis kreasi dari kearifan lokal. Ditinjau dari tiga tahapan dalam proses koreografi, maka kuantitas pertemuan sebanyak 16 kali pertemuan, dirasa kurang memadai dalam pencapaian hasil koreografi.

Dalam menghadapi kondisi tersebut maka dosen memerlukan strategi yang ampuh dan mampu mendukung keberhasilan pembelajaran. Kehadiran smartphone sebagai sebagai salah satu dari sekian gadget terpopular dan menjadi kebutuhan mahasiswa, menjadi ciri dari era digital. Merespon hal tersebut, maka dosen selayaknya menanggapinya sebagai alat bantu pembelajaran khususnya diluar jadwal kelas untuk mempermudah penyampaian materi, menciptakan situasi kelas yang menarik, dan meningkatkan kualitas pembelajaran.

Singkat kata, bahwa smartphone sebagai media pembelajaran memberikan berbagai manfaat bagi mahasiswa dan dosen. Keduanya berupaya menjalin proses pembelajaran dua arah yang efektif, menyenangkan dan interaktif diluar jadwal kuliah (tidak tatap muka) dengan mengoptimalkan penggunaan smartphone. Pemanfaatannya melalui aplikasi dan perangkat yang terdapat pada smartphone antara lain; whatsapp, instagram, google,email dan youtube. Didapatkan bahwa smartphone sebagai media pembelajaran mata kuliah koreografi dan komposisi tari I telah memberikan manfaat sebagai alat penelusuran informasi, alat komunikasi yang dimanfaatkan sebagai ruang konsultasi serta menjadikan smartphone sebagai alat bantu untuk merekam dengan menggunakan kamera untuk mengabadikan segala proses dan hasil koreografi. Hasilnya, angkatan 2017 memiliki arsip dokumen proses dan hasil pembelajaran.

Penggunaan smartphone sebagai media pembelajaran masih memerlukan arahan yang bijak yang mengandalkan peran dosen sebagai pendidik. Sebab, kelemahan mengunakan smartphone adalah mampu menjadikan penggunanya kecanduan dan melupakan realita. Hal ini dapat diantisipasi dalam perwujudan pembuatan tata tertib penggunaan smartphone dalam pembelajaran sehingga mudah dalam aksi kontrol dan mengurangi resiko penyalahgunaan. Penelitian ini memungkinkan untuk dikembangkan lebih lanjut melalui tahap evaluasi agar mampu menjadi kegiatan yang menunjang kemajuan sumber daya manusia dan dunia pendidikan Indonesia. 
Gita Kinanthi Purnama Asri / LENTERA Jurnal Ilmiah Kependidikan

Vol. 14 No.2 (Juli - Desember 2019 Edisi Dies Natalis XXXIV) 65-74

\section{DAFTAR RUJUKAN}

Anwar. (2004). Pendidikan kecakapan Hidup (Live Skills Education). Bandung: Penerbit :Alfabeta.

Hadi, Y Sumandiyo, (2011), Koreografi : Bentuk - Teknik - Isi, Yogyakarta: Cipta Media.

Ismanto, Edi. Novalia, Melly \& Herlandy,Pratama Benny. (2017). Pemanfaatan Smartphone Android Sebagai Media Pembelajaran Bagi Guru Sma Negeri 2 Kota Pekanbaru Jurnal Untuk Mu Negeri VOL. 1, NO.1

Khafidli Firgiawan, M. (2013). Pengaruh Smartphone terhadap Interaksi Sosial Mahasiswa di Kota Tangerang. Anima, Indonesian Psychological Journal, 28 (1), 131-142

Maria, Intan Trivena, Daeng N.N, Mewengkang Edmon R Kalesaran (2017). Penggunaan Smartphone Dalam Menunjang Aktivitas Perkuliahan Oleh Mahasiswa Fispol Unsrat Manado. E-journal "Acta Diurna" Volume VI. No. 1.

Musfiqon. 2012. Pengembangan Media dan Sumber Pembelajaran. Jakarta: Prestasi Pustakaraya.

Sugiyono. 2018. Metode Penelitian kuantitatif, kualitatif dan R\&D. Bandung : Alfabeta.

Tafonao, Talizaro. (2018). Peranan Media Pembelajaran Dalam Meningkatkan Minat Belajar Mahasiswa. Jurnal Komunikasi Pendidikan, Vol.2 No.2.

Widyastutieningrum, Sri Rochana dan Wahyudiarto, Dwi. 2014. Pengantar Koreografi. Surakarta: ISI Press Surakarta.

https://mediaindonesia.com/read/detail/267359-wujudkan-pendidikan-40-jaditantangan- besar-bagi-nadiem (Kamis 24 Oktober 2019, 16:00 WIB) 